\title{
ANÁLISE DOS JOGOS TRADICIONAIS E SEU CONTEXTO NAS OLIMPÍADAS RURAIS DE JAGUARI/RS ${ }^{1}$
}

Recebido em: 07/01/2016

Aceito em: 03/09/2016

Silvester Franchi

Universidade Federal de Santa Maria

Santa Maria - RS - Brasil

Sabrine Damian da Silva

Universidade de Lleida

Lleida - Espanha

João Francisco Magno Ribas

Universidade Federal de Santa Maria

Santa Maria - RS - Brasil

RESUMO: Os Jogos Tradicionais são compreendidos como o conjunto de manifestações que perduraram ao longo do tempo, transmitidos através das gerações, de forma oral, podendo estar relacionados com festejos religiosos, colheitas, tempo livre e estações do ano. Neste estudo foram identificados, descritos, analisados e caracterizados os jogos tradicionais realizados nas Olimpíadas Rurais de Jaguari/RS. Esta pesquisa descritiva e explicativa foi realizada a partir de registro e análise dos jogos tradicionais, visando interpretar este fenômeno e compreender suas determinações. As manifestações encontradas, apesar de apresentarem características esportivas, estão fortemente relacionadas com o contexto de vida das comunidades rurais de Jaguari, transformandose em um importante espaço de interação social, com a participação de homens e mulheres, adultos e crianças, idosos e jovens.

PALAVRAS CHAVE: Jogos e Brinquedos. Características Culturais. Atividades de Lazer.

\section{ANALYSIS OF TRADITIONAL GAMES AND ITS CONTEXT IN THE RURAL OLYMPICS OF JAGUARI/RS/BRAZIL}

ABSTRACT: The Traditional Games are understood as a set of manifestations that lasts over the time, which are transmitted orally through the generations, it can be related to religious feasts, crops, free time and seasons of the year. In this study we identified, described, analysed and sorted the Traditional Games of Rural Olympics of Jaguari city, in Rio Grande do Sul, Brazil. This descriptive and explanatory research was carried out from the register and analysis of the Traditional Games, in order to

\footnotetext{
1 Projeto desenvolvido com bolsa de iniciação científica do Fundo de Incentivo à Pesquisa da Universidade Federal de Santa Maria.
} 
interpret this phenomenon and understand its determinations. The manifestations found, despite showing sporting characteristics, they are strongly related to the life context of Jaguari rural communities, becoming an important space of social interaction, with the participation of men and women, adults and children, old and young people.

KEYWORDS: Play and Playthings. Cultural Characteristics. Leisure Activities.

\section{Introdução}

O Jogo Tradicional é compreendido como uma atividade humana produtiva e como elemento constituinte da cultura corporal, por entender que essa manifestação é construída historicamente e faz parte da forma como determinadas comunidades produzem a sua existência. A maneira de produzir a existência não depende diretamente do jogo, porém, esse é parte da totalidade em que os sujeitos interagem em determinado contexto.

Duarte (2006) aponta que a atividade do ser humano deve ser entendida como uma atividade histórica e produtora de história, ou seja, do desenvolvimento humano, do processo de humanização da natureza e do próprio ser humano. Assim, a categoria atividade é central para compreender as manifestações da cultura corporal, como, por exemplo, o jogo, assumindo grande relevância no entendimento dos processos sociais de humanização.

É importante fundamentar a atividade a partir de seu conceito histórico-social, em que é considerada a forma pela qual o indivíduo se relaciona com a realidade, tendo em vista a produção e reprodução das condições necessárias à sua sobrevivência material e espiritual. Essa categoria só pode ser entendida na unidade entre sujeito e objeto, do ser humano e seu contexto material.

Parte-se do pressuposto de que qualquer estudo sobre o jogo deve levar em consideração sua característica de pertencimento ao contexto em que está inserido, tal 
como observa Elkonin (1998), que se contrapõe à ideia de estudar a brincadeira ou o jogo de maneira fragmentada, isolada da totalidade da condição humana e das determinações recíprocas entre indivíduo e sociedade. De forma fragmentada, não se entenderá o jogo como "[...] atividade peculiar, como forma especial de sua vida e de sua vinculação à realidade circundante" (ELKONIN, 1998, p. 23).

Na relação entre a atividade e a totalidade é possível identificar que

[...] os jogos populares perdem seus significados diante das novas condições de vida geradas pelo processo de industrialização e urbanização da sociedade moderna. Através de um processo de dominação cultural, as manifestações culturais perdem seus significados originais (LAVEGA et al., 2011, p. 2).

E, ainda, "[...] as mudanças tecnológicas e culturais pelas quais passa o conjunto das sociedades tendem a provocar o abandono dos costumes antigos e a substituir práticas do passado por novos comportamentos" (MARIN et al., 2012, p. 74).

Os jogos investigados neste estudo são denominados Jogos Tradicionais, que, de acordo com Lavega (2006), é definido como o conjunto de manifestações que sobreviveram ao longo do tempo, transmitidas através das gerações, geralmente pela oralidade. Parlebas (2012) complementa essa ideia indicando que os jogos tradicionais são intrinsicamente caracterizados pela cultura local, a partir de festejos religiosos e de colheitas, tempo livre e estações do ano.

Para Parlebas (2012), os jogos tradicionais, em relação aos esportes, têm uma característica fundamental de diferenciação, a institucionalização, ou seja, cada esporte tem entidade que padroniza as formas de realização (regras e normas), o futebol, o voleibol, modalidades do atletismo. Este processo de institucionalização indica que os esportes, quando vinculados às instituições, devem ser realizados da mesma forma em qualquer parte do mundo, com os mesmos regulamentos. Huizinga (1971) explica que a 
esportivização acarreta a perda das características lúdicas do jogo. As características esportivas não estão presentes nos jogos tradicionais, pois esses, mesmo em povoados de uma mesma cidade, apresentam diferenças em algumas regras em que são flexibilizadas as características da comunidade local, sendo geralmente praticados com finalidade lúdica.

A Praxiologia Motriz, idealizada pelo professor Pierre Parlebas, apresenta elementos para análise da estrutura e dinâmica de funcionamento das manifestações da cultura corporal (jogos, esportes e outras manifestações motrizes). Para tanto, há uma série de conceitos que nos ajudam a desvelar a gramática das situações motrizes, ou seja, a lógica interna de cada manifestação, sendo elementos integrantes da lógica interna: a relação entre os sujeitos; a relação dos sujeitos com os materiais, com o tempo e com o espaço. Esse sistema de diferentes relações em cada situação motriz exige o surgimento de diferentes ações motrizes ${ }^{2}$ e de diferentes condutas motrizes ${ }^{3}$. Tendo em vista os aspectos socioculturais a que os jogos aportam, o objetivo desta pesquisa será o de identificar, descrever, analisar e caracterizar os jogos tradicionais manifestados nas Olimpíadas Rurais da cidade de Jaguari/RS (lógica interna), considerando os elementos do contexto sociocultural que envolve o evento (lógica externa). A partir dessas objetivações que foram propostas para a pesquisa, acreditamos no aprofundamento da construção de conhecimentos acerca dos jogos tradicionais como manifestações a serem abordadas como próprias do trabalho pedagógico da educação física.

\footnotetext{
2 Ações que surgem a partir das normas e que culminam no que pode ser observado em cada manifestação.

${ }^{3}$ Conduta Motriz, segundo Parlebas (2012), é a ação motriz enquanto portadora de significado singular de cada sujeito.
} 


\section{Metodologia}

O estudo dos Jogos Tradicionais no Rio Grande do Sul recentemente foi tema de um importante trabalho de pesquisa publicado em forma de livro por Marin e Ribas (2013). Esse estudo evidenciou a falta de registro e entendimento dos Jogos Tradicionais no Rio Grande do Sul, indicando a necessidade de um volume maior de pesquisas nesta temática. Essa pesquisa, que apresenta características descritivas e explicativas, além do registro e análise dos jogos tradicionais, busca interpretar este fenômeno e compreender suas determinações, conforme propõe Severino (2007), no processo de análise das relações da lógica interna (conceitos da Praxiologia Motriz) dos Jogos Tradicionais, como a lógica externa (contexto). As técnicas utilizadas para aprofundamento na questão central do estudo foram a entrevista semiestruturada, a análise documental (impresso e digital) e o registro de fotos e vídeos do evento.

Tendo em vista a proposta de pesquisar os jogos tradicionais manifestados nas Olimpíadas Rurais da cidade de Jaguari/RS, o estudo foi dividido, metodologicamente, em quatro fases de execução. Primeiramente, entramos em contato com o Sindicato Rural do município de Jaguari, para pedir permissão para realização do estudo, assim como para confirmar a realização do evento para o ano de 2013. A partir desse contato, agendamos entrevistas com os representantes de cada instituição envolvida na organização das Olimpíadas Rurais, sendo 1 (um) representante do Sindicato Rural, 1 (um) do Sindicato dos Trabalhadores e 1 (um) da Secretaria de Agricultura.

As entrevistas foram realizadas de forma semiestruturada com auxílio de um roteiro. A escolha por um roteiro de entrevista semiestruturada deu-se pela versatilidade que representa, tendo como característica a presença de questões abertas e fechadas, em que o sujeito entrevistado está à vontade para discorrer sobre o assunto, sem estar 
“engessado" na questão formulada (MINAYO, 2007), bem como os pesquisadores estão à vontade para aprofundar em algum ponto que acharem necessário.

As entrevistas foram realizadas de maneira individualizada, gravadas (gravador de voz ICD-PX240) e, posteriormente, transcritas para compreensão sobre a organização do evento. Todos os entrevistados assinaram o Termo de Consentimento Livre e Esclarecido.

$\mathrm{Na}$ segunda fase foram realizadas coletas de informações a respeito dos contextos econômico, social e cultural do município pesquisado. Foram utilizados como fonte de pesquisa o site da Prefeitura Municipal de Jaguari e do Instituto Brasileiro de Pesquisa e Estatística (IBGE). Complementamos as informações sobre o contexto, em documentos oficiais, cedidos pela Secretaria de Turismo e Educação do Município, em visita que realizamos a esta no intuito de agregar mais subsídios para a pesquisa.

$\mathrm{Na}$ terceira etapa do estudo, os pesquisadores acompanharam, no dia 20 de outubro de 2013, a realização da $7^{\text {a }}$ Olimpíada Rural de Jaguari na comunidade do Marmeleiro, realizando registros em fotos e filmagens dos jogos manifestados. Essa etapa do estudo foi necessária para que pudéssemos complementar as informações relativas às formas de realizações dos jogos, já que essas informações se apresentavam incompletas no regulamento.

Por fim, na quarta fase, realizamos a identificação, descrição, análise e caracterização dos jogos, sendo utilizado nessa etapa, além dos materiais/recursos já mencionados, o "Regulamento das Modalidades Esportivas", disponibilizado pelos organizadores do evento. A análise dos jogos foi realizada buscando identificar as características intrínsecas em cada jogo, a partir dos elementos da lógica interna. Os jogos foram classificados de acordo com o Sistema de Classificação de jogos e esportes 
proposto pela Praxiologia Motriz (PARLEBAS, 1987), o qual considera dois elementos da lógica interna: a interação entre os jogadores e a interação desses com o espaço.

O critério relativo à interação entre jogadores diz respeito a uma interação entre indivíduos, acompanhada de uma dedução constante de informação relativa ao comportamento dos diferentes participantes (PARLEBAS, 2003). Essa interação pode existir ou não, o que estabelece duas situações motrizes: situações psicomotrizes, quando não há interação com outros jogadores, ou seja, não há interação com companheiros nem adversários, o jogador atua sozinho, como, por exemplo, no lançamento de dardo; e situações sociomotrizes, que possuem em sua essência algum tipo de interação, podendo ser de três tipos: situações de cooperação ou comunicação motriz, quando o jogador tem que facilitar a leitura das suas ações para seu companheiro; situações de oposição ou contracomunicação motriz, quando o jogador tem que dificultar ao máximo a leitura das suas ações pelo seu adversário; e situações de cooperação-oposição, em que há interação de cooperação com companheiros e oposição com adversários, como, por exemplo, no jogo de taco.

O outro critério, relativo à interação dos jogadores com o entorno físico, é entendido pela informação que o sujeito deduz sobre o espaço material onde o jogo é realizado. O entorno físico é caracterizado por dois tipos: domesticado e selvagem. Por assim dizer, o meio domesticado pode ser compreendido quando o meio físico é conhecido do praticante, ou seja, o participante não terá a necessidade de desprender seu tempo na realização de leitura de informações referentes ao meio porque este já será amplamente reconhecido, caracterizando-se como um meio padrão/estável; em contrapartida, a dimensão de selvagem referente ao entorno físico exige que o 
participante leia a todo o momento as informações do meio para se adequar as suas exigências, caracterizando-se como um meio incerto/instável.

Combinando os critérios relativos ao entorno físico com os critérios relativos à interação entre jogadores, a Praxiologia Motriz propõe oito categorias que compõem o Sistema de Classificação, também conhecido como CAI, que são as iniciais de Companheiro, Adversário e Incerteza. Na Figura 1 são representadas em forma de árvore as oito categorias do Sistema de Classificação, de maneira que, quando houver ausência de algum dos critérios, este será representado com uma linha abaixo da letra correspondente.

Figura 1 - Representação em árvore das oito categorias do Sistema de Classificação (CAI) parlebasiano

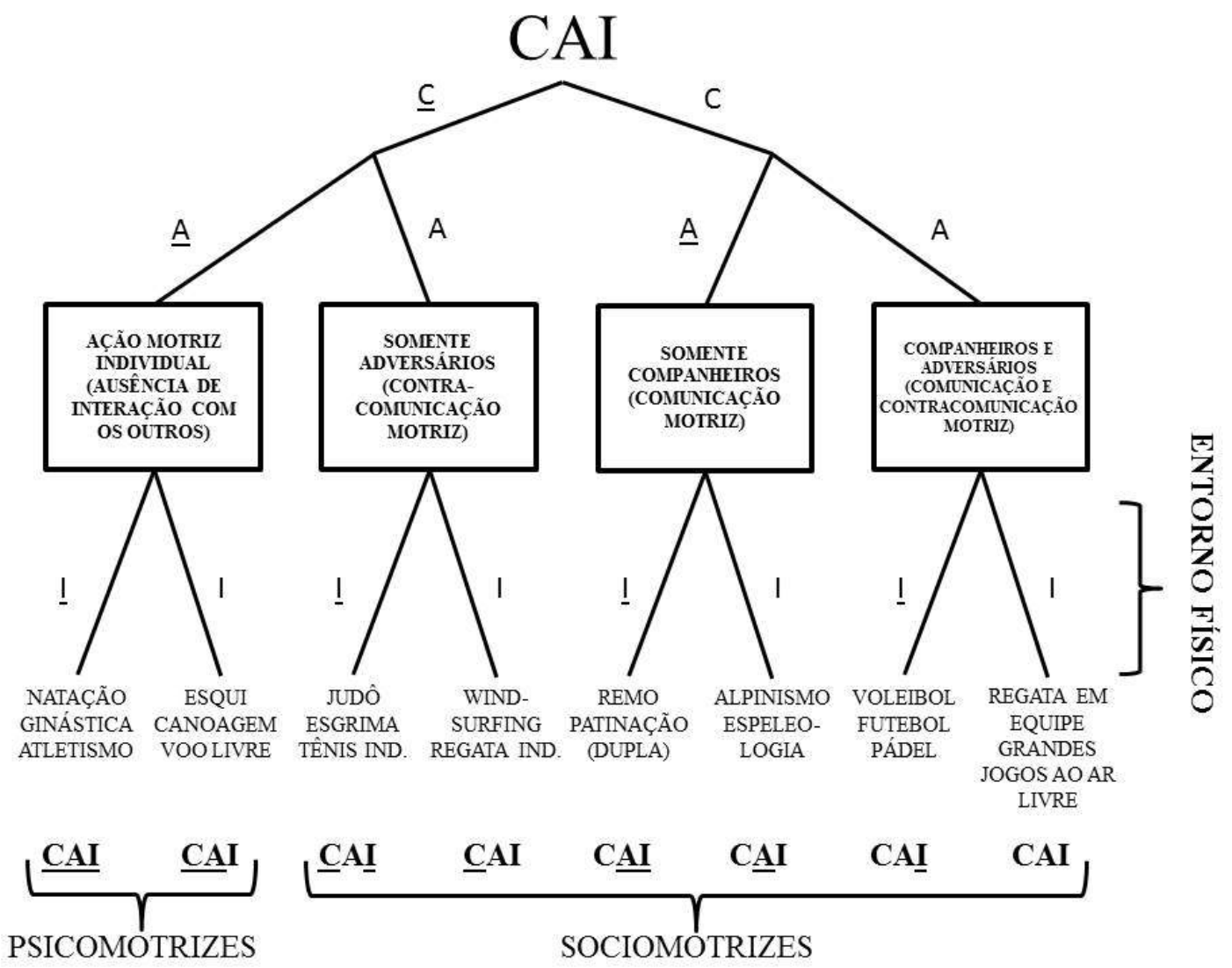

Fonte: (Figura adaptada de PARLEBAS, 1987, p. 18). 
Além da classificação dos jogos de acordo com o CAI, também foram analisados outros elementos referentes à lógica interna, sendo eles: a interação com possíveis materiais e com o tempo.

A relação do(s) jogador(es) com o(s) material(is) se refere à presença ou ausência de objetos indispensáveis para a realização do jogo, sendo jogos com material aqueles que possuem algum tipo de objeto como elemento imprescindível para o seu desenvolvimento; e jogos sem material aqueles que não possuem nenhum tipo de objeto como elemento imprescindível para a sua realização.

A relação do(s) jogador(es) com o tempo leva em consideração o modo como o jogo é finalizado, podendo ser: por pontuação limite, quando o jogo atinge uma determinada pontuação estabelecida (exemplo: voleibol); por tempo limite, quando o jogo é desenvolvido dentro de um espaço de tempo, em que o resultado da partida é estabelecido pela pontuação alcançada até o término do tempo regulamentar (exemplo: futebol); por pontuação e tempo limite, que são jogos que permitem a contabilização mista, ou seja, terminam quando se chega a pontuação determinada ou se prolongam até o tempo preestabelecido (exemplo: golpe ippon no judô, que termina a luta antes do tempo preestabelecido); por finalização da tarefa, em jogos que finalizam quando se cumpre a tarefa estabelecida pelo jogo (exemplo: arremesso de peso); e por causas externas, quando o jogo não leva em conta acertos e erros, não soma pontos, típico de alguns jogos tradicionais, quando o jogo termina pela vontade dos jogadores, seja por cansaço, por estar escurecendo o dia, ou qualquer outro motivo (exemplo: escondeesconde; pega-pega). 


\section{Resultados e Discussão}

\section{O Contexto de Estudo e a Organização da $7^{a}$ Olimpíada Rural de Jaguari}

O município de Jaguari teve como primeiros habitantes os índios Guaranis em 1632, com a fundação da redução de São Tomé, na margem direita do Rio Jaguari. Há notícia sobre a existência de outras reduções na região, entretanto, a mais próspera foi a de São Tomé, situada onde atualmente se localiza o município de Jaguari. São Tomé, como as demais reduções, não teve um período de duração muito longo. Tais reduções passaram por vários transtornos, como a ameaça de onças, pestes, fome e o perigo da invasão bandeirante, fatores que reduziram consideravelmente a população da aldeia de São Tomé, sendo ela transferida para a margem direita do Rio Uruguai, por volta de 1638 (JAGUARI, 2013).

Anos se passaram e, em 1889, foi criada a colônia de Jaguari com imigrantes italianos, seguidos por russos, poloneses, húngaros, alemães e outros, acomodados em lotes urbanos e rurais, organizando suas habitações e plantações em meio à mata. Formaram-se então comunidades, sempre com trabalho, religiosidade e espírito participativo em festas e jogos como fator de integração, o que levou a colônia a um progresso notável, passando a ser, em 1893, um distrito. Com atividades agrícolas, industriais e comerciais em desenvolvimento, Jaguari alcançou uma grande estrutura em ativa correspondência com a capital e cidades vizinhas, possibilitando sua emancipação, decretada em 16 de agosto de 1920 (JAGUARI, 2013).

Atualmente, segundo o IBGE (2010), o município de Jaguari pertence à microrregião de Santa Maria, estando, aproximadamente, $105 \mathrm{Km}$ distante deste, e a $400 \mathrm{Km}$ da capital do Estado do Rio Grande do Sul, Porto Alegre. A superfície do 
município de Jaguari é de $685,30 \mathrm{Km}^{2}$, com uma população de 11.473 habitantes, sendo, aproximadamente, $43 \%$ da população residente do meio rural (IBGE, 2010).

Em relação ao contexto de organização das Olimpíadas Rurais, podemos destacar que é realizada por volta de 15 pessoas, o que provém da parceria de três entidades relacionadas ao desenvolvimento rural do município - o Sindicato dos Trabalhadores Rurais (STR), a Empresa de Assistência Técnica e Extensão Rural (Emater) e a Prefeitura Municipal, através da Secretaria de Desenvolvimento Agropecuário. Essas entidades discutem aspectos estruturais e também recorrem à avaliação da última Olimpíada Rural para realizarem possíveis alterações, a fím de melhorar o desenvolvimento das atividades.

No dia do evento estão envolvidas de 30 a 40 pessoas, divididas entre a organização dos jogos e responsáveis pela organização de almoço, venda de lanches e bebidas. A comunidade-sede da $7^{\mathrm{a}}$ Olimpíada Rural de Jaguari foi a comunidade do Marmeleiro, a qual se demonstrou, no dia do evento, muito empenhada na arrecadação de verba, oferecendo a venda de diversos lanches e bebidas.

A venda de produtos durante a realização do evento serve de motivação para a participação das comunidades, pois a comunidade-sede do evento é responsável pela venda de comidas e bebidas, em que a comunidade detém os lucros dessa venda. Esses lucros são utilizados para ações culturais, festivas, esportivas, bem como construções/reformas nos espaços de lazer da sede da comunidade. Nas comunidades rurais geralmente não se tem uma fonte fixa de arrecadação (a exemplo de mensalidades de associados) para a realização das ações durante o ano.

O objetivo central das Olimpíadas Rurais é a integração das comunidades do interior do município de Jaguari. Há outros objetivos secundários que, a nosso ver, não 
são menos importantes, como resgatar a cultura e história das práticas laborais cotidianas através de jogos relacionados a essas práticas; integrar jovens, mulheres e idosos às manifestações; incentivar a criação de espaços de lazer nas comunidades.

As Olimpíadas Rurais têm um importante vínculo com a cultura local, conforme ressaltado pelos entrevistados nesse estudo. $\mathrm{O}$ evento, além de realizar jogos esportivos que possibilitem a integração da população rural, também retrata, por meio de jogos, as atividades cotidianas do labor rural, que foram ou ainda são vividas pela população rural.

Conforme já mencionado, a integração é o principal objetivo do evento, e para sua realização sempre é pensada uma data do ano que possibilite a participação massiva da população rural do município. Para tanto, o evento é geralmente realizado no terceiro domingo de outubro, pois é a época do ano que a população rural menos tem trabalho pendente em suas lavouras, levando em consideração que a principal produção do município é o tabaco. O evento ocorre na manhã e tarde do domingo estabelecido. A divulgação do evento geralmente é realizada por meio do programa de rádio do Sindicato dos Trabalhadores Rurais, que ocorre semanalmente na rádio municipal, sendo este o meio pelo qual há maior difusão de informações até o interior do município.

Os recursos que são utilizados para a concretização do evento provêm do valor das inscrições dos participantes e de patrocínios de agências bancárias. Esses recursos em dinheiro são utilizados na compra dos prêmios aos vencedores, sendo troféus e medalhas. A prefeitura é encarregada na preparação dos espaços em que ocorrem os jogos, disponibilizando funcionários e máquinas. Outra importante participação da 
prefeitura é a disponibilização de ônibus no dia do evento para o transporte dos participantes e de sua comunidade até a comunidade que está sediando o evento.

Os materiais utilizados nas manifestações esportivas são emprestados das escolas municipais e os materiais utilizados nos jogos tradicionais (milho, areia, cavalo etc.) são cedidos pela comunidade e/ou participantes que os têm. Geralmente, as comunidades dispõem de espaços para realizar as festividades.

As equipes são organizadas por cada comunidade, as quais têm seus representantes responsáveis. Cada comunidade recebe uma ficha de inscrição com a qual cada participante se inscreve na(s) modalidade(s). As comunidades que são pequenas têm o direito de se juntar com outra para reunir maior número de componentes.

A comissão organizadora é responsável pela arbitragem e pelo registro das pontuações. Há uma divisão na arbitragem quanto aos jogos esportivos e jogos tradicionais: nos primeiros, há um professor de educação física voluntário do município que realiza a arbitragem, e em anos anteriores já houve ajuda de alunos de educação física da UFSM; já nos jogos tradicionais são as pessoas do Sindicato dos Trabalhadores Rurais que realizam a mediação. Notamos uma questão interessante no quesito arbitragem. De acordo com o regimento do evento, nenhum jogador pode intervir diretamente com o árbitro, se necessário deve ser feito por um participante da comunidade que não esteja atuando no jogo.

A pontuação do evento é dada por provas, sendo que dentro dos pontos acumulados pelas equipes também são pontuadas as equipes com maior número de integrantes e a equipe que tenha elegido a rainha jovem e a rainha da terceira idade das Olimpíadas. 
Como já mencionado, as Olímpiadas Rurais têm como premiação troféus e medalhas. Todavia, o mais esperado como premiação é a próxima comunidade que sediará o evento, considerando que não é decidido apenas pela equipe que ganhou as Olimpíadas, mas sim pela equipe mais bem colocada que não tenha sediado o evento nos últimos cinco anos.

\section{Jogos Manifestados nas Olimpíadas Rurais}

Os jogos manifestados na $7^{\text {a }}$ Olimpíada Rural de Jaguari perfazem um total de 18 jogos, sendo eles: bocha casal, cabo de guerra, três sete, encilha e monta de cavalo, tiro de bodoque, chute ao alvo, rústica, corrida de revezamento $4 \times 50$, circuito rural (serrar lenha, debulha de milho, furo com arco de pua), tiro de laço - vaca parada -, arremesso de milho no balaio, circuito de carro de lomba, competição de pênaltis, futsal, voleibol $4 \times 4$, salto em distância, salto em altura e arremesso de peso. Logo, resultamnos para análise e discussão 17 manifestações motrizes, pois o jogo três sete não pode ser analisado através dos critérios da lógica interna e CAI por não se concretizar por meio de ações motrizes; logo, faremos algumas considerações a esse jogo a partir da categoria de jogos de azar de Caillois (1990).

Percebe-se, neste evento, que há algumas manifestações que, à primeira vista, a partir da sua nomenclatura, remetem-nos a esportes (a exemplo: voleibol, futsal, modalidades de atletismo). No entanto, ao analisarmos a forma como essas manifestações estão presentes no evento, verificou que elas não estão submetidas às normas/regras institucionalizadas das instituições esportivas, estando próximas às características dos jogos tradicionais. 


\section{a) Situações Psicomotrizes em Meio Estável (CAI):}

\section{Encilha e monta de cavalo}

Nessa prova, o participante recebe o cavalo e todos os apetrechos necessários, sendo que, para iniciar, o participante deve estar deitado sobre os apetrechos do cavalo, devendo obedecer à seguinte ordem de materiais para encilha: bucal, freio, bacheiro, carona, basto, peiteira, rabicho, cincha, pelegos, badana, sobrecincha e laço. Esses são os materiais fundamentais para a realização da prova. Para finalizar a tarefa, o participante deve montar o cavalo encilhado. Em caso de não cumprimento da ordem dos materiais, haverá desclassificação.

Essa manifestação é somente realizada por homens adultos. Acreditamos que isso se deve ao fator de que culturalmente o homem é quem realizava/realiza as tarefas rurais relacionadas à atividade pecuária. Portanto, essa manifestação parte do que chamamos cotidiano do meio rural, pois se caracteriza como uma tarefa em que as pessoas utilizavam e/ou utilizam cavalos para locomoção e afazeres do meio rural.

A finalização da prova ocorre somente com a finalização da tarefa, ou seja, quando o participante monta o cavalo, é parado o cronômetro. A prova é cronometrada para fins de classificação dos participantes e pontuação geral das comunidades no evento, vencendo quem completar a prova no menor tempo possível.

\section{Tiro de bodoquelestilingue}

Essa prova consiste em derrubar latas a uma distância de sete metros, em que cada competidor deve levar o seu bodoque/estilingue e oito pedras. Nessa, de acordo com o regulamento, somente participam jogadores nascidos do ano de 1999 em diante. Caracteriza-se como uma prova mista, ou seja, podem participar tanto pessoas do sexo masculino quanto do feminino. 
Os materiais, como citado anteriormente, são: um bodoque/estilingue (porte do jogador), oito pedras (porte do jogador) e cinco latas de refrigerantes, utilizadas como alvo. Não há regras quanto às características dos materiais portados pelos participantes.

O espaço onde se realiza o jogo é um gramado. Há uma raia da qual o jogador deve se posicionar atrás para realizar o "tiro". A uma distância de sete metros da raia, há uma tábua suspensa por outras duas, a uma altura de aproximadamente 1,5 metros, onde cinco latas estão postas uma ao lado da outra.

Os jogadores devem acertar o máximo de latas possível. Os cinco melhores na $1^{\mathrm{a}}$ fase passam a fazer mais uma série de tiros de bodoque/estilingue, novamente com oito pedras, a partir do que será conhecido o campeão. Dessa forma, a finalização do jogo ocorre após terminar a tarefa.

\section{Chute ao alvo}

A prova consiste em realizar cinco chutes, alternadamente entre os participantes, tentando acertar um alvo posicionado a certa altura do chão e à distância de cinco metros do participante.

Essa manifestação está dividida em duas modalidades: para nascidos no ano de 1999 em diante e participantes com mais 40 anos (não há diferença de regras entre as modalidades), podendo haver a participação tanto do sexo masculino quanto do feminino, caracterizando-se como manifestação de participação mista.

O espaço de jogo é uma das goleiras de um campo de futebol, onde é colocado, amarrado por cordas, um círculo de metal, que tem, aproximadamente, 70 centímetros de diâmetro. Utiliza-se uma bola de futebol para a realização dos chutes. 
O jogo é disputado em cinco chutes por participante. Ao final dos cinco chutes, quem acertar mais no alvo é o vencedor. Em caso de empate é realizado desempate com mais três chutes alternados entre os participantes empatados, até que se tenha um vencedor. Bem como as manifestações anteriores, essa prova termina ao finalizar-se a tarefa.

Tiro de laço - Vaca parada (dupla)

Esta manifestação tem o objetivo de simular o tiro de laço ${ }^{4}$, comum em rodeios. O animal é representado por um crânio de vaca/boi acoplado a um cavalete (FIGURA 2), sendo esse o alvo para o participante acertar. A competição é disputada por competidores a pé, segurando o laço.

Nessa manifestação há duas modalidades, uma para nascidos de 1999 em diante e outra para adultos. Ocorre de forma mista, podendo, assim, haver a participação de pessoas do sexo masculino e do feminino.

Como materiais são utilizados apenas um laço/corda e uma "vaca parada". Vale ressaltar que a vaca parada é confeccionada artesanalmente, sendo essa uma característica dos jogos tradicionais, nos quais, em muitos jogos, os materiais são construídos pelos próprios participantes e/ou pessoas do entorno.

Quanto ao espaço de jogo, a atividade é realizada em um gramado, onde a raia de lançamento se localiza a sete passos da vaca parada, para adultos, e cinco passos, para nascidos no ano de 1999 em diante.

\footnotetext{
${ }^{4}$ No tiro de laço, o participante equipado com um laço (corda de couro) e montado sobre um cavalo deve perseguir, em uma determinada distância, um boi/vaca, tentando acertar o laço somente nos chifres do animal para pontuar.
} 
Cada componente da equipe tem direito a três armadas ${ }^{5}$. Cada armada vale um ponto e a equipe com mais pontos ganha. Em caso de empate, realiza-se uma armada por vez, até que uma equipe vença. Assim, o término da prova se dá com a finalização da tarefa.

Figura 2 - Vaca parada utilizada no evento

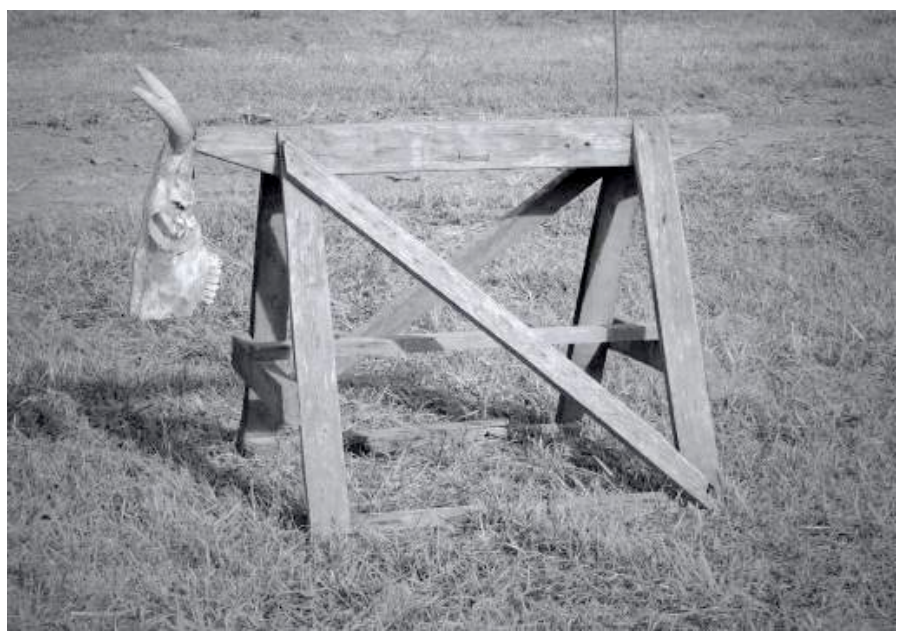

Fonte: Arquivo próprio.

\section{Arremesso de milho no balaio}

O objetivo desse jogo é acertar espigas de milho em um balaio (FIGURA 3). Os participantes se posicionam atrás de uma raia a uma distância de oito metros do alvo, devem abrir a palha e lançar a espiga no balaio. A prova é realizada em duplas formadas por um homem e uma mulher. Cada dupla recebe 10 espigas de milho para arremessar, sendo cinco para o homem e cinco para a mulher. É computado como acerto todo o milho que for encestado (cair dentro do balaio).

Essa manifestação se apresenta no evento com duas modalidades, uma para duplas nascidas no ano de 1999 em diante e outra para duplas acima de 60 anos. As duas modalidades seguem o mesmo regulamento.

\footnotetext{
${ }^{5} \mathrm{O}$ termo "armada" refere-se ao tiro de laço.
} 
Os materiais utilizados são 10 espigas de milho, sendo repostas espigas "novas" para cada dupla, e um balaio. Quanto ao espaço de jogo é realizado em um gramado.

Cada espiga encestada corresponde a um ponto. Ao final dos 10 arremessos, sagra-se campeã a dupla que obtiver mais acertos. Em caso de empate, para classificação são realizados mais seis arremessos entre os empatados, sendo três para o homem e três para a mulher. Repete-se esse procedimento até que haja uma dupla vencedora. A finalização ocorre ao finalizar a tarefa.

Figura 3 - Arremesso de milho no balaio

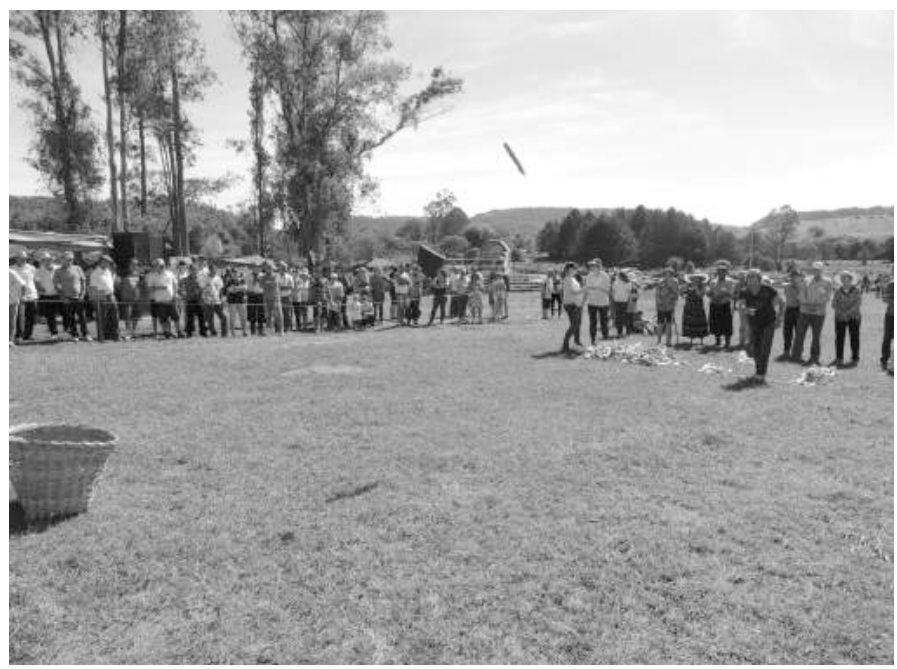

Fonte: Arquivo próprio.

\section{Salto em altura}

Consiste em transpor/saltar um sarrafo, a distância vertical mais alta possível. Cada participante terá direito a 3 saltos para transpor a mesma marca (altura), sendo que, ao final, o indivíduo que transpor a maior altura sem derrubar o sarrafo será o campeão. $\mathrm{O}$ jogador que não conseguir transpor o sarrafo na mesma altura em até 3 tentativas é desclassificado. Para a validade do salto - para que não seja "queimado" -, o participante terá de tomar impulsão com um único pé. 
Essa manifestação se apresenta com duas modalidades, masculina e feminina. A altura inicial para o sexo masculino é de $90 \mathrm{~cm}$, e para o sexo feminino é de $70 \mathrm{~cm}$. O espaço de realização, como nas outras atividades já descritas, é um gramado, e os materiais necessários para a realização da prova são um sarrafo, seu suporte e colchões. A finalização se dá quando um jogador chegar a uma altura de salto em que outro jogador não consiga superá-la em três tentativas, finalizando, assim, a prova.

\section{Salto em distância}

O objetivo dessa manifestação é saltar, horizontalmente, o mais longe possível, bem como na modalidade esportiva correspondente. Porém, essa modalidade apresenta diferenças relativas ao espaço de jogo, sendo realizada em uma "caixa de areia" adaptada ao espaço de um gramado, onde os participantes devem realizar a fase da corrida e, consequentemente, o salto na areia. Um material importante para o jogo é a trena, porém a sua utilização é exterior ao jogo, ou seja, não faz parte de sua lógica interna.

Há quatro modalidades, adulta e para nascidos de 1999 em diante, divididas entre masculino e feminino. A ordem do salto entre os participantes de cada modalidade é sorteada previamente.

São realizadas três tentativas (saltos). É considerado o melhor resultado (distância alcançada) de cada competidor. É válido o salto real, ou seja, é medido de onde o atleta tiver o último contato com o solo, até a marca mais próxima da queda. $\mathrm{O}$ salto é nulo quando: passar correndo sem saltar; der impulso à frente ou ao lado da tábua de impulsão; após completar o salto, o competidor caminhar de volta pela caixa de areia; usar qualquer forma de salto mortal. O término da prova é dado após a finalização da tarefa, ou seja, ao final das três tentativas de cada participante. 


\section{Arremesso de peso}

O objetivo da modalidade é arremessar o peso à maior distância possível, desde dentro de uma raia de arremesso, não podendo ser "queimada" ou ultrapassada.

A manifestação está presente no evento com as modalidades masculina e feminina, em que a idade para os participantes em ambas é livre.

O único material utilizado é um peso de $5 \mathrm{Kg}$ para a modalidade masculina, e para a feminina, $3 \mathrm{~kg}$ (semelhantes aos oficiais, porém antigos). O peso deve estar junto à orelha no momento do arremesso; caso contrário, será inválido (“queimado"). Cada participante tem direito a três arremessos. Vence o participante que arremessar o peso a maior distância. Desse modo, podemos observar que a prova termina ao ser concluída a tarefa.

\section{Bocha}

O jogo de bocha ${ }^{6}$ tem o objetivo de que cada equipe/dupla consiga aproximar o máximo possível suas bochas em relação ao balim. No presente evento, o jogo é disputado em duplas, sendo um homem e uma mulher, em que cada integrante da dupla deve jogar com duas bochas. Os participantes devem estar uniformizados com camisetas que identifiquem suas comunidades e estar calçando tênis apropriado.

Os materiais utilizados para esse jogo são oito bochas (quatro verdes e quatro brancas), sendo quatro para cada dupla, e um balim. As bochas são feitas industrialmente de resina sintética, possuem dez centímetros de diâmetro e cerca de 1,2 kg. O balim é fabricado com o mesmo material, porém com tamanho reduzido, com

\footnotetext{
${ }^{6}$ Para maior descrição do jogo, ver Marin e Ribas, 2013, p.160.
} 
cerca de quatro centímetros de diâmetro. O espaço de jogo é em uma cancha sintética Figura 4 de 24x4 metros, própria para esse jogo.

Os jogos são eliminatórios e disputados até oito pontos; os perdedores são eliminados da próxima fase da competição. O jogo final é realizado até 12 pontos. Destacamos, assim, que esse jogo é finalizado por pontuação, uma vez que possui uma pontuação limite para sua finalização.

Figura 4 - cancha e bochas durante uma partida

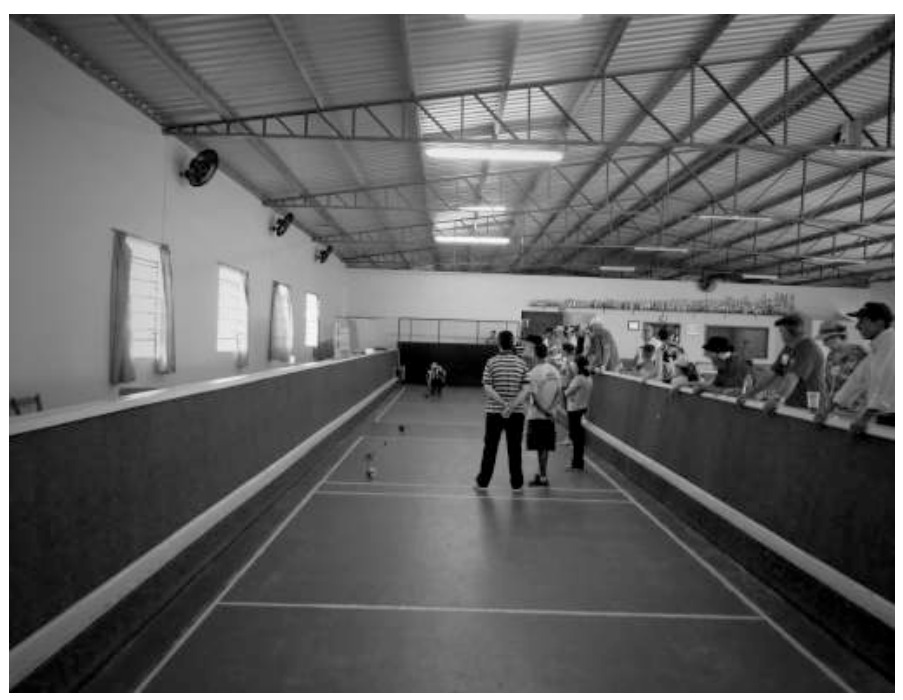

Fonte: Arquivo próprio.

\section{b) Situações Sociomotrizes de Cooperação em Meio Estável (CAI):}

\section{Corrida de revezamento $4 X 50$}

Essa manifestação é inspirada nas corridas atléticas de revezamento. O objetivo de cada equipe é chegar o mais rápido possível ao final de 200 metros, em que, a cada 50 metros, há a passada do bastão para que o próximo jogador realize seus 50 metros, e assim sucessivamente.

A corrida tem duas modalidades, uma com idade livre e outra acima de 40 anos. A equipe é formada por quatro pessoas, sendo dois participantes do sexo masculino e 
dois do sexo feminino. Cada atleta percorre $50 \mathrm{~m}$ e entrega o bastão ao companheiro. A ordem de largada de cada equipe fica a seu critério, podendo ser homem ou mulher. Os materiais utilizados nessa prova são bastões, e a pista é de grama/terra. Finaliza-se a atividade com o término da tarefa.

As provas são eliminatórias, ficando para as disputas finais as equipes vencedoras, sendo que há tantas baterias quantas forem necessárias, até à classificação dos finalistas. Em cada bateria, classifica-se o primeiro colocado, que passará para a próxima fase. Vence a equipe que fizer o percurso o mais rápido possível.

\section{Circuito rural}

Essa atividade consiste em um circuito com quatro tarefas, uma consequente à outra, em que cada equipe deve realizar todo o percurso no menor tempo possível. As tarefas são: serrar lenha com um serrote traçador; debulhar milho; abrir e fechar um portão; e fazer um furo com arco de pua (instrumento semelhante a uma furadeira, porém manual). A atividade deve ser realizada em dupla, sendo um participante do sexo masculino e o outro do sexo feminino.

O início da prova se dá na raia de largada, onde a mulher deve ser conduzida, pelo participante do sexo masculino, em cima do carro de mão até a $1^{\text {a }}$ tarefa, que é serrar lenha com um serrote traçador. Após, a dupla retorna ao carro de mão seguindo até a $2^{\mathrm{a}}$ tarefa, que é a debulha de milho em máquina, feita pelo homem, devendo a mulher deixar os sabugos limpos. Em seguida, retornam ao carro de mão deslocando-se para a $3^{\mathrm{a}}$ tarefa, na qual a mulher deve abrir e fechar um portão com cadeado. Cumprida a tarefa, eles retornam ao carro de mão e deslocam-se até a $4^{\text {a }}$ e última tarefa, que consiste em o homem fazer um furo na madeira usando um arco de pua e, após, retirá- 
lo. Por fim, seguem no carro de mão até a raia de saída, onde será encerrado o percurso, sendo vencedor quem fizer o menor tempo. Assim, temos a finalização dessa prova com o término da tarefa.

Os materiais que são utilizados para realização dessa prova são: um carro de mão, serrote traçador, pedaços de lenha, 10 espigas de milho por dupla, cadeado, arco de pua e pedaços de madeira. O espaço utilizado é um gramado com as delimitações próprias da atividade.

\section{c) Situações Sociomotrizes de Oposição em Meio Estável (CAI): \\ Competição de pênaltis}

O jogo consiste na sequência de três cobranças de pênaltis. A participação nesse jogo é somente por duplas de mulheres acima de 40 anos, sendo uma batedora e uma goleira. O jogo é realizado em uma das metas do campo de futebol, sendo a bola de futebol um material imprescindível.

São realizadas três cobranças alternadas entre duas duplas, sendo que se, ao final das três cobranças, estiver empatada a disputa, há uma cobrança alternada até que se conheça a vencedora. A finalização do jogo se dá somente após o término da tarefa.

\section{d) Situações Sociomotrizes de cooperação-oposição em meio estável (CAI) \\ Cabo de guerra \\ O cabo de guerra se caracteriza como uma luta de força entre duas equipes, com} o objetivo de sobrepujar a equipe oponente transpassando determinada demarcação da corda em relação ao terreno de jogo. As equipes são formadas por 6 jogadores e 1 
reserva; há somente a participação de homens. Os jogadores, obrigatoriamente, devem estar descalços para a disputa.

Como material é utilizada uma corda de cerca de 20 metros com três marcas (panos atados na corda): uma centralizada e duas marcas, cinco metros para cada lado a partir da marca centralizada; as duas marcas serão a designação em que cada uma das equipes segura a corda para o início da disputa. O terreno de jogo é um gramado com uma demarcação no solo, onde a marca central da corda deve corresponder a essa demarcação no solo.

O juiz, após as duas equipes estarem colocadas em seus respectivos lugares, alinha as marcas da corda e do solo, dando início ao jogo. A finalização do jogo se dá quando uma equipe conseguir puxar a marca da corda da equipe oponente até a marca no solo, ou seja, quando se termina a tarefa. As equipes, em nenhuma hipótese, podem soltar a corda durante a competição, sob pena de serem eliminadas da competição.

Essa manifestação é bastante significativa no mundo dos jogos tradicionais, em que podemos encontrá-las em diversas etnias diferentes, tais como a alemã, a italiana, a portuguesa e a indígena, relatadas por Marin e Ribas (2013).

\section{Futsal}

O jogo de futsal, assim chamado pela comissão organizadora, é jogado em um campo gramado, delimitado por linhas, que, na verdade, foram demarcadas através da remoção da grama. O material imprescindível para esse jogo é uma bola de futebol.

Essa manifestação tem duas modalidades, masculina e feminina, ambas com idades livres. Cada equipe deverá ser composta por cinco jogadores titulares e até cinco reservas. 
São partidas compostas por dois tempos de oito minutos. Em caso de empate no tempo normal, é feito o desempate por pênaltis (5 por equipe). As equipes deverão estar uniformizadas.

Uma curiosidade: nessa manifestação é a rigidez para com os jogadores que eventualmente sejam expulsos por agressão verbal ou física ao árbitro, adversários ou coordenadores, ocorrendo sua suspensão automática na modalidade. O árbitro será a autoridade máxima das partidas.

\section{Voleibol $4 \times 4$}

Esse jogo se apresenta semelhante ao vôlei de areia $4 \times 4$, porém com as diferenças que veremos acerca do terreno de jogo, rede e mais liberdades relativas às regras. As equipes são formadas por dois atletas do sexo masculino e dois do sexo feminino. A idade para participação é livre. A equipe poderá contar com até quatro jogadores reservas, sendo que, no decorrer de toda partida, as equipes deverão estar formadas por dois jogadores e duas jogadoras.

O terreno de jogo é bastante improvisado, sendo o solo, onde é realizado o jogo, de grama, demarcado com uma fita de isolamento; a rede colocada a uma altura definida pela organização, respeitando as características dos jogadores e não seguindo o modelo institucionalizado esportivo (FIGURA 5). As regras são mais flexíveis quanto às ações motrizes realizadas; assim, as faltas, como toque na rede, invasão, condução de bola, dois toques etc., são acordadas entre o juiz e os participantes antes do início da partida. Essa situação de acordo entre os participantes e juiz, quando houver, é muito semelhante ao pacto firmado por jogadores no início de jogos tradicionais (LAVEGA, 
2000). Os materiais utilizados nesse jogo são rede de voleibol, postes, bola de voleibol e fita para delimitar o espaço de jogo.

A partida é disputada em melhor de três sets de 15 pontos cada. A equipe terá que ganhar dois sets para ser vencedora, sendo que deverá ocorrer uma diferença mínima de dois pontos para a finalização do set. Ocorrendo empate na chave de classificação entre duas ou mais equipes, o desempate será feito por sorteio. A arbitragem será a autoridade máxima da partida, sendo que casos omissos serão resolvidos junto à Comissão Organizadora. Desse modo, podemos caracterizar a finalização desse jogo como por pontuação.

Figura 5: Voleibol 4x4

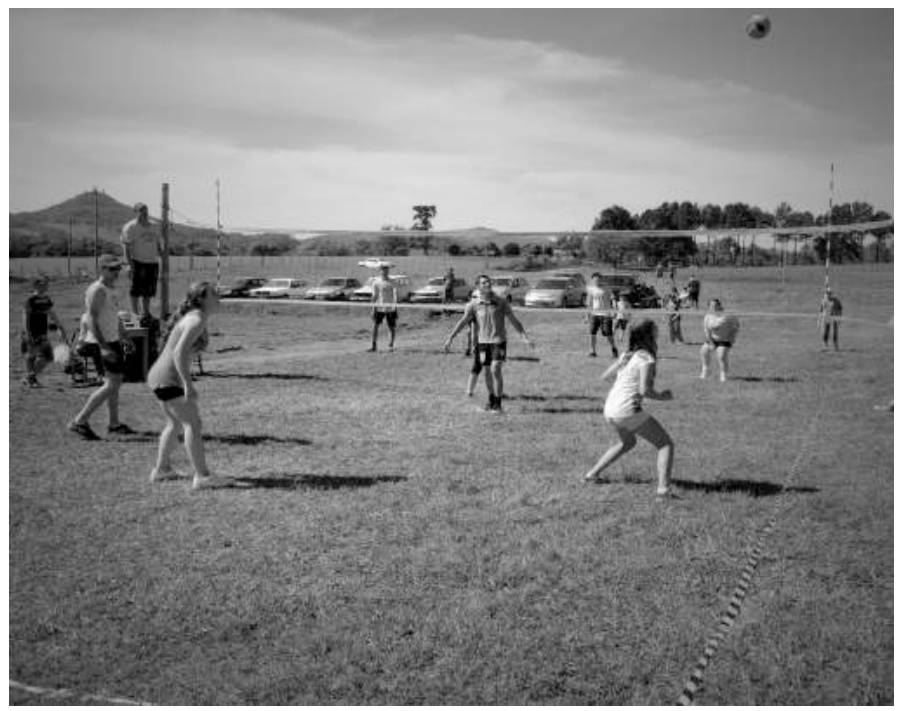

Fonte: Arquivo próprio.

\section{e) Situações Psicomotrizes em Meio Instável (CAI):}

\section{Rústica}

Como o nome diz, essa manifestação é uma corrida rústica, cuja característica principal, no caso do evento que está sendo analisado, é a irregularidade do terreno, 
impondo, desse modo, aos participantes ter que vigilar o terreno para que tenham êxito. Especificamente, o terreno de disputa é "estrada de chão" (terra e pedras) e gramado.

A rústica se apresenta com quatro modalidades: masculina, com idade livre; feminina, com idade livre; masculina, com nascidos no ano de 1999 em diante; e feminina, com nascidas no ano de 1999 em diante. As distâncias estabelecidas são de 2 $\mathrm{km}$ para o masculino livre, $1 \mathrm{~km}$ para o feminino livre, $1 \mathrm{~km}$ para o masculino nascido em 1999 em diante, e 600 m para o feminino nascido em 1999 em diante. Para essa prova não há materiais necessários para o seu desenvolvimento.

A finalização da tarefa se dá a partir da ordem de chegada dos participantes.

\section{f) Situações Sociomotrizes de Cooperação em Meio Instável (CAI):}

Circuito de carro de lomba

Consiste em percorrer um circuito demarcado em um campo irregular, onde o carro é conduzido por um atleta e empurrado por outro.

Essa manifestação é disputada em duas modalidades, para nascidos no ano de 1999 em diante, e adulto, em que a dupla pode ser masculina, feminina ou mista. Ao completar metade da volta ao redor do circuito, as posições dos participantes são invertidas, ou seja, o que estava empurrando, senta, e o que estava sentado, empurra.

O material utilizado é um carro de lomba (FIGURA 6). A finalização dessa prova se dá com o término da tarefa, sendo vencedora a dupla que realizar o percurso no menor tempo. 
Figura 6: Carro de lomba com os jogadores

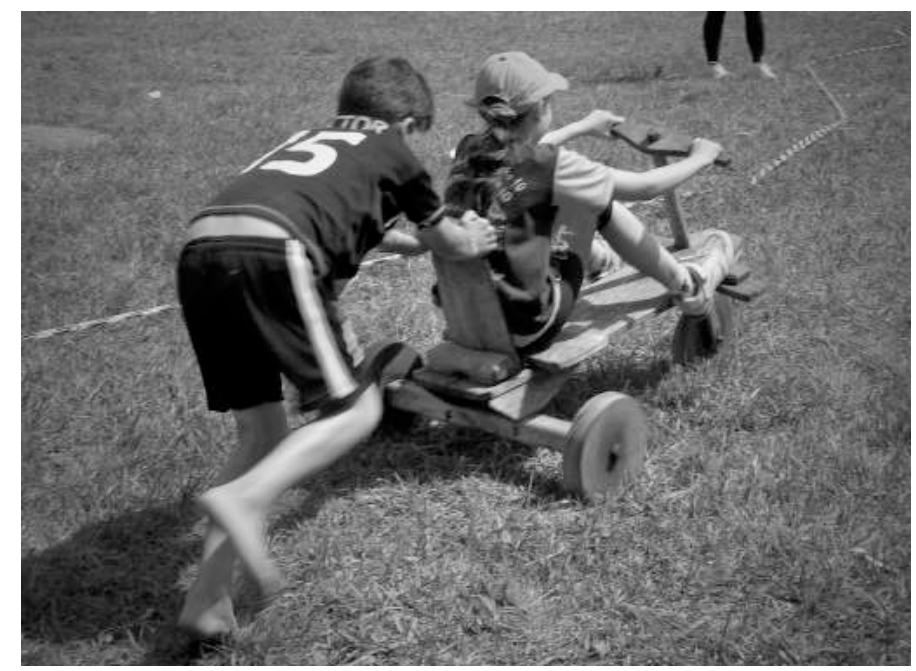

Fonte: Arquivo próprio.

Três sete

O jogo de Três Sete é um jogo tradicional, porém, como dito anteriormente, não é de caráter motriz, logo não se pode realizar a classificação por meio do CAI. Todavia, pode-se categorizá-lo como um jogo de azar, em que Caillois (1990) afirma que os jogos de cartas são classificados em duas das quatro categorias de jogos propostas pelo autor - Agôn e Alea -, os jogos que se podem treinar e se comparam os resultados a jogos de sorte, respectivamente. Dessa maneira, o desenvolvimento do jogo de Três Sete se dá a partir da responsabilidade individual (experiência do participante quanto ao jogo) e da entrega ao destino (caso da sorte ao receber as cartas).

Postos os resultados empíricos referentes às manifestações culturais encontradas no evento estudado, para melhor visualização, sistematizamos as informações no (QUADRO 1).

\footnotetext{
${ }^{7}$ Considerando que as regras desse jogo de cartas são bastante extensas, sugerimos que, conforme interesse do leitor, consulte-se Marin e Ribas (2013, p. 174).
} 
Quadro 1 - Sistematização de elementos referentes às manifestações encontradas.

\begin{tabular}{|c|c|c|c|c|c|c|c|c|c|c|c|c|}
\hline \multirow[t]{2}{*}{ Manifestação } & \multirow{2}{*}{$\begin{array}{c}\text { Localização } \\
\text { no Sistema de } \\
\text { Classificação }\end{array}$} & \multicolumn{3}{|c|}{ Presença e Origem dos Materiais } & \multirow{2}{*}{$\begin{array}{c}\text { Relação dos } \\
\text { jogadores como } \\
\text { tempo }\end{array}$} & \multicolumn{4}{|c|}{ Idade de Prática } & \multicolumn{3}{|c|}{ Sexo } \\
\hline & & Natureza & Artesanal & $\begin{array}{c}\text { Insdustrializado } \\
\text { /Adaptado }\end{array}$ & & Crianças & $\begin{array}{l}\text { Jovens/ } \\
\text { Adultos }\end{array}$ & \begin{tabular}{|c|} 
Acima de 40 \\
anos e \\
Idosos \\
\end{tabular} & Livre & Feminino & Masculino & Misto \\
\hline Encilha e monta de cavalo & \multirow{9}{*}{$\begin{array}{c}\text { Psicomotrizes } \\
\text { em meio } \\
\text { estável }\end{array}$} & & $\mathrm{x}$ & $\mathrm{X}^{*}$ & Finalização da tarefa & & $\mathrm{x}$ & & & & $\mathrm{x}$ & \\
\hline Tiro de bodoque/ es tilingue & & $\mathrm{X}$ & $\mathrm{X}$ & $\mathrm{X}^{*}$ & Finalização da tarefa & $\mathrm{X}$ & & & & & & $\mathrm{X}$ \\
\hline Chute ao alvo & & & & $\mathrm{X}$ & Finalização da tarefa & $\mathrm{X}$ & & $\mathrm{X}$ & & & & $\mathrm{X}$ \\
\hline $\begin{array}{l}\text { Tiro de laço - vaca parada } \\
\text { (dupla) }\end{array}$ & & $\mathrm{X}$ & $\mathrm{X}$ & $\mathrm{X}^{*}$ & Finalização da tarefa & $\mathrm{X}$ & $\mathrm{x}$ & & & & & $\mathrm{x}$ \\
\hline Arremesso de milho no balaio & & $\mathrm{X}$ & $\mathrm{X}$ & & Finalização da tarefa & $\mathrm{X}$ & & $\mathrm{X}$ & & & & $\mathrm{X}$ \\
\hline Salto em altura & & & & $\mathrm{X}$ & Finalização da tarefa & & & & $\mathrm{X}$ & $\mathrm{X}$ & $\mathrm{X}$ & \\
\hline Salto em dis tância & & \multicolumn{3}{|c|}{ Sem material } & Finalização da tarefa & $\mathrm{X}$ & $\mathrm{X}$ & & & $\mathrm{X}$ & $\mathrm{X}$ & \\
\hline Arremesso de peso & & & & $\mathrm{x}$ & Finalização da tarefa & & & & $\mathrm{X}$ & $\mathrm{X}$ & $\mathrm{X}$ & \\
\hline Bocha & & & & $\mathrm{x}$ & $\begin{array}{l}\text { Finalização por } \\
\text { pontuação limite }\end{array}$ & & & & $\mathrm{X}$ & & & $\mathrm{X}$ \\
\hline Corrida de revezamento $4 \times 50$ & \multirow{2}{*}{\begin{tabular}{|c|} 
Sociomotrizes \\
de \\
cooperação \\
em meio \\
estável \\
\end{tabular}} & \multicolumn{3}{|c|}{ Sem informações } & Finalização da tarefa & & & $\mathrm{X}$ & $\mathrm{X}$ & & & $\mathrm{X}$ \\
\hline Circuito rural & & $\mathrm{X}$ & $\mathrm{x}$ & $\mathrm{X}^{*}$ & Finalização da tarefa & & $\mathrm{x}$ & & & & & $\mathrm{x}$ \\
\hline Competição de pênaltis & $\begin{array}{c}\text { Sociomotriz } \\
\text { de oposição } \\
\text { em meio } \\
\text { estável } \\
\end{array}$ & & & $\mathrm{X}$ & Finalização da tarefa & & & $\mathrm{X}$ & & $\mathrm{X}$ & & \\
\hline Cabo de guerra & \multirow{3}{*}{\begin{tabular}{|c} 
Sociomotrizes \\
de \\
cooperação- \\
oposição em \\
meio estável
\end{tabular}} & & & $\mathrm{X}^{*}$ & Finalização da tarefa & & $\mathrm{X}$ & & & & $\mathrm{X}$ & \\
\hline Futsal & & & & $\mathrm{X}$ & $\begin{array}{c}\text { Finalização por } \\
\text { tempo limite }\end{array}$ & & & & $\mathrm{X}$ & $\mathrm{X}$ & $\mathrm{X}$ & \\
\hline Voleibol 4x4 & & & & $\mathrm{x}$ & $\begin{array}{l}\text { Finalização por } \\
\text { pontuação limite }\end{array}$ & & & & $\mathrm{X}$ & & & $\mathrm{X}$ \\
\hline Corrida rústica & $\begin{array}{c}\text { Sociomotriz } \\
\text { de oposição } \\
\text { em meio } \\
\text { instável }\end{array}$ & \multicolumn{3}{|c|}{ Sem material } & Finalização da tarefa & $\mathrm{X}$ & & & $\mathrm{X}$ & $\mathrm{X}$ & $\mathrm{X}$ & \\
\hline Circuito carro de lomba & $\begin{array}{c}\text { Sociomotrizes } \\
\text { de } \\
\text { cooperação } \\
\text { em meio } \\
\text { instável } \\
\end{array}$ & & $\mathrm{X}$ & & Finalização da tarefa & $\mathrm{X}$ & $\mathrm{X}$ & & & & Livre & \\
\hline Três sete & & & & $\mathrm{X}$ & Finalização da tarefa & & $\mathrm{X}$ & $\mathrm{X}$ & & & $\mathrm{X}$ & \\
\hline
\end{tabular}

*São considerados materiais industrializados, porém, a finalidade desses materiais é o labor cotidiano e não a utilização nas manifestações lúdicas.

Os elementos que caracterizam a manifestações desenvolvidas nas Olimpíadas Rurais de Jaguari apresentam grande semelhança e aproximação às atividades do cotidiano das pessoas que vivem e sobrevivem no/do meio rural. Corroborando os dados encontrados, Lavega (2000) se refere ao surgimento de jogos a partir do domínio das tarefas básicas de sobrevivência de culturas antigas, como caça, produção de alimentos, utilização de instrumentos em tarefas básicas.

$\mathrm{O}$ autor acima referido menciona o uso de animais nas tarefas cotidianas das comunidades rurais, considerando-os imprescindíveis. Nesse sentido, os jogos com 
animais tomam um caráter de competição lúdica para provar qual agricultor tem melhores animais (LAVEGA, 2000). Assim sendo, percebe-se nos jogos da encilha de cavalo e tiro de laço com vaca parada (utilizada de forma representada) a utilização de animais, porém, não ocorre com o objetivo de comparar o potencial dos animais e, sim, as habilidades dos jogadores.

Quanto à localização dos jogos no Sistema de Classificação, podemos notar grande caracterização de jogos psicomotrizes, lembrando que esses são jogos em que os participantes atuam sozinhos. Dos 17 jogos classificados, 9 pertencem à referida categoria, ao momento que 8 são sociomotrizes. Os jogos tradicionais de diferentes etnias do Rio Grande do Sul expressam ainda mais a superioridade de manifestações psicomotrizes em detrimento das sociomotrizes, perfazendo um total de $75 \%$ de jogos psicomotrizes e apenas 25\% sociomotrizes (SILVA, 2015). Relação oposta ocorre em outros contextos, a exemplo do estudo de Elloumi e Parlebas (2009), ao estudarem 120 jogos tradicionais tunisianos, em que, no contexto estudado pelos pesquisadores, $82 \%$ dos jogos são sociomotrizes e apenas $18 \%$ são psicomotrizes. Os autores aproximam o resultado da classificação com o desenvolvimento sociocultural da Tunísia, pois o povo deste país sempre defendeu combativamente de seus territórios e destruição de seus inimigos.

Quanto às características dos participantes, analisamos duas categorias: faixa etária e o sexo para o qual é oferecido o jogo. Desde esse ponto, discutiremos alguns aspectos que acreditamos merecer destaque. O primeiro deles é a interação entre participantes de diferentes idades em um mesmo jogo. Encontramos sete jogos que têm a possibilidade de participação livre, ou seja, desde criança até velhos podem jogar a mesma modalidade. A reunião de faixas etárias até idosos nos demonstra o caráter 
educativo que os jogos tradicionais podem desenvolver nos indivíduos que estão compartilhando as emoções de jogar, possibilitando, como afirma Lavega (2006), a transmissão de conhecimento e costumes, socialização e interação com as demais pessoas, bem como aprender a se relacionar com os espaços mais representativos da comunidade em que cada um vive. As outras 10 manifestações estão divididas entre a participação em uma ou duas das três categorias: crianças; jovens/adultos; e acima de 40 anos e idosos.

Outro ponto que merece ênfase é a participação mista em relação ao sexo; isso significa dizer que existe a interação entre homens e mulheres em uma mesma modalidade. Essa relação encontrada em alguns jogos da presente pesquisa se difere do que culturalmente acontece em nossa sociedade, em que os homens são designados a tarefas que demonstram a virilidade, a força, enquanto que as mulheres são responsáveis por tarefas sutis, delicadas (SANTIAGO, 2013). Em várias culturas, podem-se identificar jogos tradicionais que são desenvolvidos por homens e outros que são desenvolvidos por mulheres, como, por exemplo, jogos com colaboração, habilidades estilizadas e com presença de cantigas geralmente são detidas como de mulheres/meninas; em contrapartida, demonstrações de força, violência e enfrentamento corporal estão mais relacionados a homens/meninos (LAVEGA, 2006). Mesmo havendo o rompimento com essas características sociais, em três manifestações da presente pesquisa ainda encontramos expressa a relação de gênero presente na sociedade.

A primeira das manifestações é o Cabo de Guerra, a qual se caracteriza pela comparação da força bruta de duas equipes. Algo semelhante acontece na Encilha $e$ Monta de Cavalo, pois essa manifestação é recorrente nas tarefas relacionadas à 
pecuária e está caracterizada pelo labor, quase que exclusivo, do homem. O terceiro jogo que possui também essa relação é o Três Sete, que é, costumeiramente, jogado em bares e com a presença de aposta de dinheiro (MARIN, 2013); esses dois elementos são característicos do cotidiano de homens de pequenos povoados.

Dentre os 17 jogos das Olimpíadas Rurais de Jaguari, 15 são realizados com o espaço de jogo caracterizado como estável, ou seja, os participantes do jogo não necessitam ler as informações que o próprio meio de prática oferece, pois não há mudanças no espaço de jogo. Pode-se inferir que as manifestações realizadas em forma de um evento de competição entre diferentes equipes/comunidades se aproximam da lógica do esporte de rendimento, bem como afirma Parlebas (2003) sobre a tendência de o esporte ser a domesticação do espaço, para que seja possível estandardizar a prática.

A relação dos jogadores com materiais é bastante presente nos jogos realizados no evento das Olimpíadas Rurais de Jaguari, pois foram identificados 16 jogos com presença de objetos indispensáveis para a sua realização, sendo apenas dois jogos realizados sem quaisquer materiais. Os resultados referentes a essa categoria estão de acordo com os resultados da pesquisa de Silva (2015), que ao analisar os jogos tradicionais de diferentes grupos sociais do estado do Rio Grande do Sul, diagnosticou que $97,7 \%$ dos jogos têm interação dos jogadores com algum tipo de objeto imprescindível para a realização do jogo.

Os jogos que possuem materiais possibilitaram a análise desses quanto a sua origem a partir de três categorias: 1) provindos da natureza, que são materiais que não sofreram nenhuma transformação, ou essa foi mínima, como, por exemplo, uma pedra e uma fruta; 2) construídos artesanalmente, são materiais que o processo de construção é realizado por pessoas que seguem uma maneira própria de elaboração dos objetos, 
como, por exemplo, um arco e flecha construídos pelo próprio jogador ou por seus pais; e 3) industrializado/adaptado, que são materiais confeccionados de forma industrializada, comprados em lojas; esse pode ser ainda adaptado para os jogos, uma vez que não tenham sua finalidade para a utilização em jogos, como, por exemplo, uma colher, uma lata de refrigerante, que são retirados do ambiente do entorno domiciliar ou do espaço social cotidiano para ser utilizado em um jogo.

Em 4 jogos são utilizados materiais do próprio entorno (natureza), 6 são realizados com materiais artesanais e 13 com materiais industrializados. Com relação aos industrializados, deve-se destacar que em 5 situações são materiais confeccionados de forma industrial, utilizados, porém, com outra finalidade, a laboral, ressaltando-se que os 8 jogos em que são utilizados materiais industrializados em sua maioria são relacionados às manifestações esportivas, em que somente o jogo de bocha e o três sete são considerados jogos tradicionais. Nos jogos tradicionais há a relação bastante forte da própria produção de materiais pelos próprios jogadores, ou seja, conforme Lavega (2006), em muitos casos os jogadores são os artesãos de seus próprios objetos de jogo.

Por fim, em relação ao aspecto temporal, ou seja, a forma com que o jogo é finalizado, encontramos que a grande maioria das manifestações (15 jogos) encontradas no evento findam com o término da tarefa, apenas duas manifestações terminam por meio de uma pontuação limite, e uma finaliza com um tempo preestabelecido. Novamente correlacionando ao estudo de Silva (2015), podemos notar aproximação com o presente estudo, pois, em sua maioria, os jogos terminam após cumprir-se a tarefa. Os jogos tradicionais em seu realizar-se espontâneo têm o seu modo de finalização a partir de elementos exteriores a sua lógica interna; isso quer dizer que pode finalizar, por exemplo, por ser a hora de comer, por falta de luminosidade natural, por 
cansaço, dentre outras formas (SILVA, 2015), algo que não aconteceu no evento aqui analisado, pois isso não foi possibilitado pelo caráter competitivo desenvolvido nos jogos, diferindo, a exemplo, de festivais de jogos que são realizados com a finalidade de vivenciar e experienciar as manifestações.

\section{Considerações Finais}

O jogo tradicional é uma manifestação que transmite comportamentos, ações e possibilidades de criar e agir a partir de elementos contextuais, locais e relacionados a grupos sociais, sendo muito importante para a Educação Física, considerando que o jogo tradicional é um dos seus conhecimentos. As manifestações de jogos tradicionais encontradas nas Olimpíadas Rurais estão fortemente relacionadas com o contexto sóciohistórico de produção e reprodução da vida das comunidades rurais de Jaguari. Observou-se que os jogos são apropriados pela população, havendo forte engajamento dos organizadores e participantes em promovê-lo.

Utilizando os conhecimentos que a praxiologia motriz propõe no âmbito das situações/manifestações motrizes, foi realizada uma concreta análise dos jogos encontrados nas Olimpíadas Rurais do Município de Jaguari, valorizando o evento e os jogos apresentados em seu seio cultural. Bem como Parlebas, ao idealizar a Praxiologia Motriz, não considera uma situação motriz superior a outra, senão com objetivos e características distintas. Assim, não se deveria haver uma hierarquização do esporte em relação ao jogo tradicional, do jogo tradicional em relação às atividades na natureza (PARLEBAS, 2012).

As Olimpíadas Rurais se caracterizam como um evento de competição entre diferentes comunidades rurais, porém, paradoxalmente a essa característica, o evento se 
transforma em um grande espaço de interação social, que reproduz o cotidiano, ou seja, sem a distinção de homens e mulheres, adultos e crianças, idosos e jovens. Torna-se importante destacar também a estreita necessidade de materiais para a realização dos jogos, havendo em alguns jogos a utilização de materiais que são próprios do labor rural, e os objetos provindos da natureza, transformados em elementos lúdicos para a concretização das manifestações corporais.

Uma relação importante a se destacar é quanto ao espaço de realização das manifestações, o qual se caracteriza rumo à padronização dos espaços de jogo. Essa constatação a partir da análise da lógica interna dos jogos condiz com as imposições que a sociedade moderna/capitalista traduz como objetivos esportivos ao buscar a igualdade de chances (BRACHT, 2011), almejando qualificar/quantificar os resultados.

Por último, acreditamos ser necessário destacar a importância dos Jogos Tradicionais enquanto conteúdos da educação física escolar. Afirmar a importância como um conteúdo significa dizer que os jogos tradicionais devem ser trabalhados pedagogicamente a partir de suas próprias características e não como reféns de outros conteúdos $^{8}$. Para tanto, tem-se ainda o déficit de discussões que apontem proposições concretas rumo à construção de métodos, estratégias e técnicas de ensino para o trato pedagógico com os conhecimentos acerca dos Jogos Tradicionais. Destarte, buscaremos em próximas pesquisas contribuir para o cerre de algumas lacunas pendentes de discussões a partir das singularidades do contexto brasileiro.

\footnotetext{
${ }^{8}$ A exemplo, considerar os jogos tradicionais como jogos pré-desportivos, bem como utilizá-los como um meio para o desenvolvimento cognitivo ou motor, sem a considerar as implicações socioculturais.
} 


\section{REFERÊNCIAS}

BRACHT, V. Sociologia crítica do esporte: Uma introdução. Ijuí: Editora Unijuí, 2011.

CAILlOIS, R. Os Jogos e os Homens: A Máscara e a Vertigem. Lisboa: Edições Cotovia Ltda, 1990.

DUARTE, N. Vigotski e o "aprender a aprender": crítica às apropriações neoliberais e pós-modernas da teoria vigotskiana. 4. ed. Campinas: Autores Associados, 2006.

ELLOUMI, A.; PARLEBAS, P. Análise sociocultural dos jogos esportivos tradicionais tunisianos. Fitness Performance Journal, Rio de Janeiro, v. 8, n. 2, p. 136-145, mar./abr. 2009. Disponível em: http://www.redalyc.org/pdf/751/75112591010.pdf. Acesso em: 20 nov. 2015.

ELKONIN, D. Psicologia do Jogo. São Paulo: Martins Fontes, 1998.

HUIZINGA, J. Homo ludens: O jogo como elemento da cultura. São Paulo: Perspectiva, 1971.

IBGE - Instituto Brasileiro de Geografia e Estatística. Censo demográfico 2010. Rio de Janeiro, 2010.

JAGUARI. Prefeitura Municipal de Jaguari, 2013. Disponível em: http://jaguari.rs.gov.br/.

LAVEGA BURGUÉS, P. Juegos y Deportes Populares-Tradicionales. Barcelona, INDE Publicaciones, 2000.

. El juego y la tradición en la educación de valores. Educación Social, Barcelona, n.33, p. 54-72, 2006. Disponível em: http://www.raco.cat/index.php/EducacioSocial/article/viewFile/165535/373786. Acesso em: 11 nov. 2014.

. et al. Os Jogos Tradicionais no Mundo: associações e possibilidades. Revista

Licere: Belo Horizonte, v.14, n.2, jun/2011. Disponível em: http://www.anima.eefd.ufrj.br/licere/pdf/licereV14N02 re1.pdf. Acesso em: 9 ago. 2014.

MARIN, E. C. et al. Jogos Tradicionais no Estado do Rio Grande do Sul: manifestação pulsante e silenciada. Revista Movimento: Porto Alegre, v. 18, n. 03, p. 73-94, jul/set de 2012. Disponível em: http://seer.ufrgs.br/Movimento/article/viewFile/26564/21140. Acesso em: 25 out. 2014.

UFSM, 2013.

.; RIBAS, J. F. M. (Org.). Jogo tradicional e cultura. Santa Maria: Editora

MARIN, E. C. Grupo social Italiano. In: MARIN, E. C.; RIBAS, J. F. M. (Org.). Jogo tradicional e cultura. Santa Maria: Editora UFSM, 2013. 
MINAYO, M. C. S. Trabalho de campo: contexto de observação, interação e descoberta. In: . (org.) Pesquisa social: teoria, método e criatividade. 25. ed. Petrópolis: Vozes, 2007, p. 61-77.

PARLEBAS, P. Perspectivas para una educación física moderna. Málaga: UNISPORTE, 1987. 2003

Elementos de sociología del deporte. Málaga: Instituto Andaluz del Deporte,

Léxico de Praxiologia Motriz. Badalona: Editorial Paidotribo, 2012.

SANTIAGO, M. G. Corpo, gênero e sexualidade: um diálogo com as professoras dos anos iniciais. 2013. 57 f. Monografia (Especialização) - Centro de Educação Física e Desportos, Universidade Federal de Santa Maria, Santa Maria, 2013.

SEVERINO, A. J. Metodologia do Trabalho Científico. São Paulo: Cortez, 2007.

SILVA, S. D. Jogos Tradicionais organizados no estado do Rio Grande do Sul: uma aproximação etnomotriz. 2015. 185 f. Dissertação (Mestrado) - Centro de Educação Física e Desportos, Universidade Federal de Santa Maria, Santa Maria, 2015.

\section{Endereço dos Autores:}

Silvester Franchi

Rua Gregório de Matos, 611,

Bairro Camobi, Santa Maria, RS, Brasil - CEP 97105-700.

Endereço Eletrônico: silvesterfranchi@hotmail.com

Sabrine Damian da Silva

Rua Lluis Companys, 40, 5D, 25003

Lleida, Lleida - Espanha

Endereço Eletrônico: sabrinedamian@hotmail.com

João Francisco Magno Ribas

Universidade Federal de Santa Maria

Centro de Educação Física e Desportos

Avenida Roraima, $\mathrm{n}^{\circ} 1000$ - prédio 51 - Bairro Camobi

Santa Maria - RS - 97.105-900

Endereço Eletrônico: ribasjfm@hotmail.com 